\title{
BMJ Open Establishment of a communication environment supporting low-health literacy in the Hungarian community pharmacies: the introduction of a methodological recommendation: a before-after study
}

András Szilvay (D) , Orsolya Somogyi, Attiláné Meskó, Kata Szücs-Polonkai, Romána Zelkó, Balázs Hankó

To cite: Szilvay A, Somogyi 0 , Meskó A, et al. Establishment of a communication environment supporting low-health literacy in the Hungarian community pharmacies: the introduction of a methodological recommendation: a beforeafter study. BMJ Open 2020;10:e039603. doi:10.1136/ bmjopen-2020-039603

- Prepublication history and supplemental material for this paper is available online. To view these files, please visit the journal online (http://dx.doi. org/10.1136/bmjopen-2020039603).

Received 20 April 2020 Revised 01 September 2020 Accepted 10 November 2020

Check for updates

(c) Author(s) (or their employer(s)) 2020. Re-use permitted under CC BY-NC. No commercial re-use. See rights and permissions. Published by BMJ.

University Pharmacy Department of Pharmacy Administration, Semmelweis University Faculty of Pharmacy, Budapest, Hungary

Correspondence to Dr András Szilvay; szilvay.andras@pharma. semmelweis-univ.hu

\section{ABSTRACT}

Objectives The research aimed to support the effectiveness and necessity of the communication training and methodology introduced in the postgraduate pharmacy training and community pharmacy practice in Hungary.

Design Two cross-sectional questionnaire surveys before and after the introduction of a methodological recommendation.

Setting 69 Hungarian community pharmacies.

Participants The study included 333 pharmacists and pharmacy technicians from community pharmacies, 890 and 847 patients (over 18 who bought their prescribed medication) at the beginning and the end of the project, respectively.

Interventions A 3-day postgraduate health literacyfocused communication training followed by the 'Train the trainer' teaching method at pharmacies, then the introduction of the learnt methodology using uniform information materials and a communication checklist. Primary and secondary outcome measures Primary: total score of the staff and patient questionnaires and the change in score due to the intervention, total and for each question. Secondary: the differences between sexes, age groups, marital statuses, educational attainments and types of settlement.

Results The mean score of the preintervention patient group was $64.07 \%$ which increased to $72.72 \%$ by the end of the project $(p<0.001)$. For staff, the mean score of the initial questionnaires was $74.47 \%$, and that of the final questionnaires was $85.21 \%(p<0.001)$. According to both groups, professionals made the most progress in encouraging patients to ask questions.

Conclusions It can be stated that the presented methodology can be used to develop the communication skills of a large number of professionals in a short time, using a small number of instructors, so it is worthwhile to introduce this methodology as part of compulsory postgraduate training.
Strengths and limitations of this study

The project had almost nationwide coverage, including many professionals and patients.

- The success of the intervention was confirmed by two different questionnaires (patients and staff).

- Lack of control groups (other professionals who did not receive education and did not apply the methodology, and their patients).

- Selection bias: no randomisation was used in the professional, pharmacy and patient enrolment method.

- The questionnaires used were self-developed, based on experience from previous projects.

\section{INTRODUCTION}

Pharmacy and pharmacy practices have evolved around the world in response to changes in the environment around the profession and the needs of patients. The emphasis on drug distribution and preparation is shifting towards patient-centred care and counselling, where pharmacists assess the necessity, efficiency and safety of patients' medications and ensure that patients understand their therapies and monitor changes in their condition. ${ }^{1-6}$ This is facilitated by several factors. In the current healthcare setting, community pharmacies are the most accessible healthcare providers for patients. ${ }^{7}$ It has been stated that patients are more willing to talk to their pharmacist than to doctors about their illness, ${ }^{8}$ which make the pharmacists the 'the first port of call' of the healthcare system. ${ }^{7910}$ These types of pharmacy services can have many benefits: they can improve the health of patients through drug therapy and 
patient adherence management, ${ }^{11}$ contribute to reducing morbidity, mortality and health costs. ${ }^{12}$

Patient-centred and consultative community pharmacy services such as medication review, adherence improvement or health promotion require pharmacists to have strong communication skills, ${ }^{13}$ thus ensuring the optimal exchange of information and that patients are fully participating in their care. ${ }^{14-17}$

Pharmacists' communication has to adapt to different patients' needs to achieve patient centricity, ${ }^{18}$ with particular regard to the different levels of their health literacy.

Health literacy 'refers to those personal, cognitive and social skills that determine the ability of individuals to obtain, understand and use basic health information and all services aimed at promoting and maintaining a healthy lifestyle'. ${ }^{19} 20$ According to a survey, $47 \%$ of the patients have poor health literacy ${ }^{21}$; this proportion is $52 \%$ in Hungary. ${ }^{22}$ On this basis, pharmacists must provide clear and easily understandable information on the correct use of medicines to prevent, protect and improve patient health so that patients can make the most of it. ${ }^{23}$ In its 1997 report, the WHO made it clear that the future pharmacists should be effective communicators, focusing on open information exchange and patient involvement in treatment decision-making. ${ }^{14} 162324$ Pharmacist counselling rates vary worldwide from $8 \%$ to $100 \%^{25}$; moreover, according to a survey, $40 \%-80 \%$ of the information provided by health professionals is immediately forgotten by patients, while nearly half of the information are poorly remembered. ${ }^{26}$ Inadequate and inaccurate communication, self-medication and poor health literacy can easily lead to misunderstanding of medical recommendations and deviations from the prescribed treatment regimen. ${ }^{23}$ Also, it can have a negative effect on pharmacists, as poor communication can lead to a deterioration in their judgement and a loss of confidence in pharmacists' knowledge. ${ }^{627}$ In contrast, a pharmacist who is capable of effective patient-centred communication can work to improve patient adherence and health outcomes, ${ }^{28}$ and can also increase patient satisfaction. ${ }^{469}$ However, to achieve all these goals, it is essential that both graduate and postgraduate training of pharmacists be adapted to changing needs. Various international pharmacist competence frameworks emphasise communication as the core competency of pharmacists. ${ }^{30-34}$ However, these requirements are not always met in practice. ${ }^{17183536}$ Education and training can improve the communication skills of pharmacists, ${ }^{16}$ 37-39 which are needed by both pharmacy students and graduated pharmacists. ${ }^{40}$

In Hungary, two types of professional workers exist in the community pharmacies: pharmacists and pharmacy technicians. Pharmacists receive a degree after 5 years at university, while the training of pharmacy assistants lasts for 2 years. Pharmacy technicians may perform everything only under the supervision of a pharmacist. They also play a significant role in communication with the patient and drug dispensing. Only a pharmacist can dispense the medicine in some special cases (eg, interaction, side effect) regulated by law.

The healthcare institutions that cover the country most evenly are the community pharmacies operating as part of the primary care. There are about 2900 community pharmacies in Hungary, where more than 60 million pharmacist-patient meetings take place every year. The majority of patients visit pharmacies for two reasons: (1) to get a drug prescribed by a general practitioner or a specialist; (2) to seek advice on relieving their mild symptoms. During a consultation, pharmacists or pharmacy technicians dispense the prescribed drug or recommend an over-the-counter medication for the patient's symptoms. In both cases, they have to properly describe the use of medicines, for which the use of appropriate communication techniques is essential. However, during their normal programme of education, pharmacy technicians currently receive no, while pharmacists receive minimal communication training (a 3 hours lesson in the last year), so the effective and wide-ranging postgraduate training for professionals who have already graduated is crucial.

The research aimed to support the effectiveness and necessity of the communication training and methodology introduced in the postgraduate pharmacy training and community pharmacy practice in Hungary.

\section{METHODS}

\section{The research in general}

The research was conducted between January 2017 and June 2017. The implementation was carried out under the guidance of the pharmacists participating in Semmelweis University postgraduate specialist training (3-year specialisation training for graduated pharmacists), with the participation of pharmacists and pharmacy technicians they included (no financial compensation was granted) from their workplace (Hungarian community pharmacies accredited at Semmelweis University (the largest of the four universities training pharmacists in Hungary, located in Budapest, offering both graduate and postgraduate training)). No randomisation was used in the selection of pharmacists, pharmacy technicians and community pharmacies included: 73 pharmacists took place in the postgraduate training, all the other participating professionals were the colleagues, while the pharmacies where the research took place were the workplaces of these pharmacists.

\section{The description of the project}

The flow chart of the project is shown in figure 1. At the beginning of the project, graduated pharmacists participating in the postgraduate specialist training took part in a 3 days training course at Semmelweis University. They received training on health literacy, appropriate pharmacist-patient communication techniques, domestic conditions, factors behind poor health literacy and its consequences, they also learnt about the potential of 


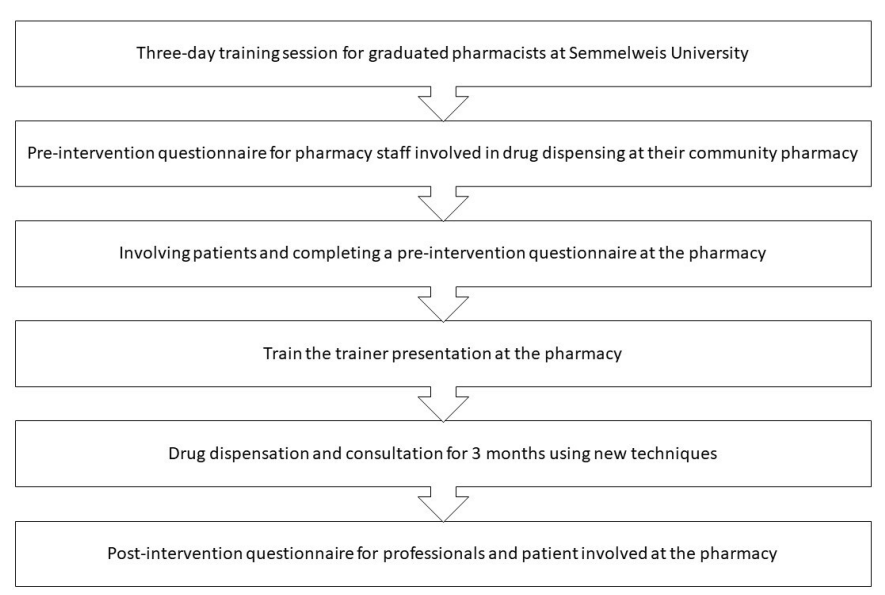

Figure 1 The flow chart of the project.

pharmacies to improve health literacy. Project requirements, methodology and questionnaires were described (see 'Communication tools in the pharmacies').

Table 1 Characteristics of patients surveyed in the project (data numbers $(n)$ other than 'the number of patients surveyed' are due to occasional deficiencies in data collection; 'other' marital status: divorced, short-term relationship or the patient cannot define it)

\begin{tabular}{|c|c|c|}
\hline & Preintervention & Postintervention \\
\hline $\begin{array}{l}\text { The number of patients } \\
\text { surveyed: }\end{array}$ & 890 & 847 \\
\hline Sex & $n=871$ & $n=830$ \\
\hline Male & $42.3 \%$ & $43.6 \%$ \\
\hline Female & $57.7 \%$ & $56.4 \%$ \\
\hline Age & $\mathrm{n}=887$ & $n=839$ \\
\hline 18-25 years & $12.0 \%$ & $12.5 \%$ \\
\hline $26-40$ years & $25.8 \%$ & $25.4 \%$ \\
\hline $41-65$ years & $37.4 \%$ & $38.0 \%$ \\
\hline 65 years- & $24.8 \%$ & $24.1 \%$ \\
\hline Marital status & $n=876$ & $\mathrm{n}=835$ \\
\hline Other & $2.4 \%$ & $1.8 \%$ \\
\hline Single & $23.7 \%$ & $22.8 \%$ \\
\hline Widowed & $19.5 \%$ & $18.8 \%$ \\
\hline $\begin{array}{l}\text { Married/long-term } \\
\text { relationship }\end{array}$ & $54.4 \%$ & $56.6 \%$ \\
\hline Educational attainment & $\mathrm{n}=876$ & $\mathrm{n}=817$ \\
\hline Primary school & $7.0 \%$ & $8.6 \%$ \\
\hline Vocational school & $24.0 \%$ & $23.1 \%$ \\
\hline Baccalaureate & $34.3 \%$ & $35.7 \%$ \\
\hline University & $34.7 \%$ & $32.6 \%$ \\
\hline Type of settlement & $n=889$ & $n=846$ \\
\hline Villages & $3.4 \%$ & $3.6 \%$ \\
\hline Other cities & $40.8 \%$ & $40.5 \%$ \\
\hline County towns & $9.7 \%$ & $10.4 \%$ \\
\hline Capital city & $46.1 \%$ & $45.5 \%$ \\
\hline
\end{tabular}

In the next step, pharmacists used a questionnaire to assess the opinions of technicians and pharmacists at their workplace about how well they think they communicate with patients in a manner appropriate to the level of patients' health literacy (see Staff questionnaire').

At the same time, patients over 18 who bought their prescribed medication were enrolled. After the consultation, patients were asked by a professional other than the dispensing technician or pharmacist, and the patients could voluntarily decide whether or not to participate in the survey. Randomisation was not used, the staff of the pharmacy had to involve about 15 patients in overall at the beginning and the end of the project. All patients surveyed were fully informed and then completed a questionnaire on the quality of the pharmacy staff's communication (see Patient questionnaire'). The language of the questionnaires was Hungarian, which is the only official language in Hungary. The Hungarian language of the questionnaire was written with the help of communication experts (MSD Pharma Hungary, Institute of Behavioural Sciences (Semmelweis University)) to fit the comprehension skills of the Hungarian society. In the next step, the pharmacists participating in the postgraduate training course educated their colleagues (train the trainer presentation ${ }^{41}$ ) on health literacy and appropriate communication techniques through a $30 \mathrm{~min}$ presentation prepared by professionals (Institute of Behavioural Sciences, Semmelweis University). All pharmacy colleagues who voluntarily participated in the research were required to attend the lecture. Pharmacy staff used the appropriate communication techniques (see 'Communication tools in the pharmacies') for 3 months with each patient entering the pharmacy, then the opinion of staff and patients (other than patients enrolled at the beginning of the project) was resurveyed using the same questionnaires, investigating the development of the pharmacies' communication.

\section{Communication tools in the pharmacies}

The participating pharmacies received a self-developed communication package, which included a 'communication checklist' (online supplemental annex 1), with eight basic communication tips for good consultation practice, and an 'Ask your pharmacist!' poster (online supplemental annex 2), which was displayed in the participating pharmacies. Also, the participating pharmacies received written patient information leaflets, which were given to patients in the framework of the project (Ask your pharmacist-patient information leaflet-online supplemental annex 3).

\section{Patient questionnaire}

The English transcription of the patient questionnaire is included in online supplemental annex 4 . The questionnaires were completed on paper, either in interviews or individually, and were conducted each time by a professional other than the person conducting the consultation. The questionnaire and scoring system were self-developed 
Table 2 Results of patient questionnaires (data numbers (n) other than 'the number of patients surveyed' (see table 1) are due to occasional deficiencies in data collection; $p$ values were determined using variance analysis and t-tests)

\begin{tabular}{|c|c|c|c|c|c|c|c|}
\hline & Questions & $\begin{array}{l}\text { Values of points } \\
\text { available for the } \\
\text { question }\end{array}$ & $\begin{array}{l}\text { Mean } \\
\text { preintervention } \\
\text { score (point) } n=889\end{array}$ & $\begin{array}{l}\text { Mean } \\
\text { postintervention } \\
\text { score (point) } \\
\mathrm{n}=846\end{array}$ & $\begin{array}{l}\text { Mean } \\
\text { change } \\
\text { (point) }\end{array}$ & $\begin{array}{l}\text { Mean } \\
\text { change } \\
(\%)\end{array}$ & $\begin{array}{l}P \\
\text { value }\end{array}$ \\
\hline 1. & $\begin{array}{l}\text { Did the pharmacist or } \\
\text { pharmacy technician use } \\
\text { complicated terms or } \\
\text { expressions during the } \\
\text { consultation? }\end{array}$ & 0/1/4 point(s) & 2.94 & 3.31 & +0.37 & +9.09 & $<0.001$ \\
\hline 2. & $\begin{array}{l}\text { Did the pharmacist or } \\
\text { pharmacy technician } \\
\text { encourage you to ask } \\
\text { questions during the } \\
\text { consultation? }\end{array}$ & & 2.35 & 3.05 & +0.70 & +17.58 & $<0.001$ \\
\hline 4. & $\begin{array}{l}\text { How easy or difficult was it } \\
\text { for you to understand the } \\
\text { instructions given by your } \\
\text { pharmacist or pharmacy } \\
\text { technician on how to } \\
\text { take/use the prescribed } \\
\text { medication? }\end{array}$ & 0-4 point(s) & 3.06 & 3.29 & +0.23 & +5.75 & $<0.001$ \\
\hline 5. & $\begin{array}{l}\text { How much do you feel } \\
\text { you know all the important } \\
\text { information about your } \\
\text { medicines? }\end{array}$ & & 2.04 & 2.26 & +0.22 & +5.58 & 0.002 \\
\hline
\end{tabular}

by communication experts from MSD Pharma Hungary, Institute of Behavioural Sciences (Semmelweis University), and pharmacists, based on previous experience (Crystal Clear Pharmacy Program, Ireland). ${ }^{42}$

The questionnaires were completed anonymously and voluntarily. In addition to sex, age, marital status and educational attainment, patients receive six questions, including three simple choice questions (question 1-3; yes/no/don't know), and three scaling questions (question 4-6; 5-point scale). To find out what patients think about pharmacists' communications overall, the responses were converted into scores (see online supplemental annex 4). The scoring system was self-developed developed to measure the development of the participants' communication skills in each targeted question and overall. The value of the points and the decisive nature of the examination questions determining the total score were decided based on professional considerations. In the case of simple choice questions (questions 1-3), positive answers for health literacy were 4 points, negative answers 1 and neutral ('don't know') answers 0 points. In the case of questions 4-6, patients were able to choose from 5 options, of which the neutral and don't know answers were 0 points, the other answers were 1-4 points, where 4 were the most positive answers. A total of 24 points were thus obtained.

\section{Staff questionnaire}

The staff questionnaire is included in online supplemental annex 5. The questionnaires were completed on paper and were filled independently, anonymously. The professionals only had to indicate the type of settlement where the pharmacy was located, and then they had to answer five questions, each of them was rated 1-5 according to how typical the given statement was $(1-$ not at all, 5-very characteristic). A total of 25 points were thus obtained. The scoring system used for evaluation (see online supplemental annex 5) was self-developed; thanks to the collaborations described above (Crystal Clear Pharmacy Programme). ${ }^{42}$

\section{Ethics approval}

The survey complied with Hungarian legal requirements (the pharmacy service was completely free and 
non-invasive). ${ }^{43-46}$ Verbal informed consent was obtained from all participants in the pharmacies (General Data Protection Regulation (GDPR) decree not yet enacted); no written consent was required according to the Act No. CLIV of 1997 on (non-invasive pharmacy service and questionnaire survey) ${ }^{43}{ }^{47}$ Informed consent was taken from the community pharmacies. The study was conducted as a free service of licensed pharmacies, with the voluntary and fully informed participation of patients. The services were provided by graduated pharmacists with licensed pharmacy technicians. The processing of the data was carried out in accordance with the Hungarian legal requirements at that time. ${ }^{43}$ The collected data were forwarded to the authors without any personal data for processing the results. The personal and health records of the patients included in the study were kept anonymous.

\section{Statistical analysis}

After descriptive statistical analysis, data composition, staff and patient questionnaires were examined for each question, total scores and degree of change in normal distribution by variance analysis and t-tests. The normality was checked by the Kolmogorov-Smirnov test. Subgroups of the two different populations were compared using the $\chi^{2}$ test. The $\chi^{2}$ test and the Kruskal-Wallis test were used to compare participants' total scores for each gender, age group, educational attainment, marital status and settlement type. Bonferroni and Scheffe tests were used to determine which group mean was significantly different from others. The significance level was set at 5\%. Statistical calculations were performed using SPSS V.20.0 (SPSS, Chicago, Illinois, USA).

\section{Patient and public involvement}

Patients or the public were not involved in the design, or conduct, or reporting, or dissemination plans of this research.

\section{RESULTS}

\section{Characteristics of surveyed pharmacies and patients}

Postgraduate education was attended by 73 pharmacists from 69 pharmacies. A total of 333 professionals participated in the whole project. The survey was close to national coverage; 14 out of 20 counties in the country (including the capital city, Budapest) had a participating pharmacy. Of the staff working in pharmacies, most took part in the project in 'other cities' $(44.7 \%)$ and in the capital $(43.5 \%)$, while a smaller proportion worked in pharmacies located in county towns $(8.4 \%)$ or village $(3.3 \%)$. Table 1 shows the patients enrolled: 890 and 847 patients participated at the beginning and end of the project, respectively.

\section{Results of the patient questionnaire}

The preintervention and postintervention groups consisted of two different patient populations. Subgroups of these two different populations were compared using the $\chi^{2}$ test and they were statistically significantly equal ( $p>0.05$; sex: $\mathrm{p}=0.569$; age: $\mathrm{p}=0.962$; marital status: $\mathrm{p}=0.676$; educational attainment: $\mathrm{p}=0.555$; type of settlement: $\mathrm{p}=0.958)$. The mean score of the preintervention patient group was 15.38 ( $\mathrm{SD}=4.89)$ points, which corresponds to $64.07 \%$. At the end of the project, patients other than this patient population completed the questionnaire, their mean score was $17.45(\mathrm{SD}=4.07)$ points, which is $72.72 \%$ of the total score, showing a significant $(p<0.001)$ improvement of $8.65 \%$ ( +2.07 points) between the two questionnaires. The improvement in the score of each question during the project has been examined, and these results are included in table 2 (maximum of 4 points per question). There was a significant improvement in all questions: the greatest was found in Question $2(+17.58 \%)$. Questions 1 and 3 showed an improvement of $9.09 \%$ and $9.77 \%$, respectively, while the mean score of questions 4-6 improved by 4\%-5\% (table 2).

The improvement of the total score of each subpopulation has been analysed to identify the groups of patients more or less affected by the project (table 3 ). The results showed that there was no significant difference between women and men $(p>0.05)$. The total score of patients older than 40 years developed significantly more than those under 40 years $(\mathrm{p}<0.001)$. Also, the development of widows $(p<0.02)$ and residents of county seats $(p<0.02)$ were significantly higher. In contrast, patients with university degrees improved less $(\mathrm{p}=0.02)$.

\section{Results of the staff questionnaire}

The mean total score of the preintervention questionnaires was 18.61 points $(\mathrm{SD}=2.97 ; 74.47 \%)$ out of 25 , with an average of 3.72 points per question. The results of the repeated questionnaires at the end of the project were 21.30 points $(\mathrm{SD}=2.32 ; 85.21 \%)$, which is 2.69 points ( 0.54 points per question), $10.74 \%$, significant increase $(\mathrm{p}<0.001)$. Examining the individual questions, it can be stated that the mean score of all questions increased significantly by the end of the project $(\mathrm{p}<0.001)$, the greatest improvement was in the case of question 4 and the least in the case of question 1 (table 4).

In results of the statistical analysis show that the results of professionals working in the county towns or the capital improved significantly more $(\mathrm{p}<0.02$; table 5$)$.

\section{DISCUSSION}

Nowadays, in Hungary, neither pharmacy students nor pharmacy technician students receive adequate communication training. As a result, the communication skills of drug dispensing staff working in community pharmacies do not meet the current international requirements of the field.

This phenomenon is also supported by the results of the preintervention questionnaires. The relatively high $74.47 \%$ mean preintervention score from staff questionnaires indicate that pharmacy staff does not consider their communication skills to be poor, which does not fully 
Table 3 Change in the score for each patient subpopulation (bold: subpopulation with significantly higher improvement; $n$ (preintervention): preintervention questionnaire data number; $n$ (postintervention): postintervention questionnaire data number; data numbers $(n)$ other than 'number of patients surveyed' (see table 1 ) are due to occasional deficiencies in data collection; $p$ values were determined using $\chi^{2}$ test and the Kruskal-Wallis test)

\begin{tabular}{|c|c|c|c|c|c|}
\hline Sex & $\begin{array}{l}\text { Mean } \\
\text { change } \\
\text { (point) }\end{array}$ & $\begin{array}{l}\text { Mean } \\
\text { change } \\
(\%)\end{array}$ & & & \\
\hline $\begin{array}{l}\text { Male } \\
\mathrm{n}(\text { preintervention })=368 \\
\mathrm{n}(\text { postintervention })=362\end{array}$ & +2.02 & +8.42 & & & \\
\hline $\begin{array}{l}\text { Female } \\
\mathrm{n}(\text { preintervention })=502 \\
\mathrm{n}(\text { postintervention })=467\end{array}$ & +2.10 & +8.75 & & & \\
\hline \multicolumn{6}{|l|}{$P>0.05$} \\
\hline Age & $\begin{array}{l}\text { Mean } \\
\text { change } \\
\text { (point) }\end{array}$ & $\begin{array}{l}\text { Mean } \\
\text { change } \\
(\%)\end{array}$ & Marital status & $\begin{array}{l}\text { Mean } \\
\text { change } \\
\text { (point) }\end{array}$ & $\begin{array}{l}\text { Mean } \\
\text { change } \\
(\%)\end{array}$ \\
\hline $\begin{array}{l}18-25 \text { years } \\
\mathrm{n}(\text { preintervention })=106 \\
\mathrm{n}(\text { postintervention })=105\end{array}$ & +1.39 & +5.79 & $\begin{array}{l}\text { Other } \\
\mathrm{n}(\text { preintervention })=21 \\
\mathrm{n}(\text { postintervention })=15\end{array}$ & +1.93 & +8.04 \\
\hline $\begin{array}{l}26-40 \text { years } \\
n(\text { preintervention })=228 \\
n(\text { postintervention })=213\end{array}$ & +1.26 & +5.25 & $\begin{array}{l}\text { Single } \\
\mathrm{n}(\text { preintervention })=208 \\
\mathrm{n}(\text { postintervention })=190\end{array}$ & +1.71 & +7.13 \\
\hline $\begin{array}{l}41-65 \text { years } \\
\mathrm{n}(\text { preintervention })=332 \\
\mathrm{n}(\text { postintervention })=318\end{array}$ & +2.43 & +10.13 & $\begin{array}{l}\text { Married/long-term relationship } \\
\mathrm{n}(\text { preintervention })=475 \\
\mathrm{n}(\text { postintervention })=473\end{array}$ & +1.86 & +7.75 \\
\hline $\begin{array}{l}\text { 65-years } \\
\mathrm{n}(\text { preintervention })=220 \\
\mathrm{n}(\text { postintervention })=202\end{array}$ & +2.59 & +10.79 & $\begin{array}{l}\text { Widowed } \\
\mathrm{n}(\text { preintervention })=171 \\
\mathrm{n}(\text { postintervention })=156\end{array}$ & +2.84 & +11.83 \\
\hline$P<0.001$ & & & $p<0.02$ & & \\
\hline Educational attainment & $\begin{array}{l}\text { Mean } \\
\text { change } \\
\text { (point) }\end{array}$ & $\begin{array}{l}\text { Mean } \\
\text { change } \\
(\%)\end{array}$ & Type of settlement & $\begin{array}{l}\text { Mean } \\
\text { change } \\
\text { (point) }\end{array}$ & $\begin{array}{l}\text { Mean } \\
\text { change } \\
(\%)\end{array}$ \\
\hline $\begin{array}{l}\text { Primary school } \\
\mathrm{n}(\text { preintervention })=61 \\
\mathrm{n}(\text { postintervention })=69\end{array}$ & +2.43 & +10.13 & $\begin{array}{l}\text { Villages } \\
\mathrm{n}(\text { preintervention })=30 \\
\mathrm{n} \text { (postintervention) }=30\end{array}$ & +0.97 & +4.04 \\
\hline $\begin{array}{l}\text { Vocational school } \\
\mathrm{n}(\text { preintervention })=210 \\
\mathrm{n}(\text { postintervention })=189\end{array}$ & +2.49 & +10.38 & $\begin{array}{l}\text { Other cities } \\
\mathrm{n}(\text { preintervention })=363 \\
\mathrm{n}(\text { postintervention })=343\end{array}$ & +2.50 & +10.42 \\
\hline $\begin{array}{l}\text { Baccalaureate } \\
\mathrm{n}(\text { preintervention })=301 \\
\mathrm{n}(\text { postintervention })=292\end{array}$ & +2.39 & +9.96 & $\begin{array}{l}\text { County towns } \\
\mathrm{n}(\text { preintervention })=86 \\
\mathrm{n}(\text { postintervention })=88\end{array}$ & +3.33 & +13.88 \\
\hline $\begin{array}{l}\text { University } \\
\mathrm{n}(\text { preintervention })=303 \\
\mathrm{n}(\text { postintervention })=266\end{array}$ & +1.67 & +6.96 & $\begin{array}{l}\text { Capital city } \\
\mathrm{n}(\text { preintervention })=410 \\
\mathrm{n}(\text { postintervention })=385\end{array}$ & +1.67 & +6.96 \\
\hline$p=0.02$ & & & $\mathrm{p}<0.02$ & & \\
\hline
\end{tabular}

coincide with the results of the patient questionnaires. These results show that the communication of the staff was not that good at the beginning of the project $(64.07 \%)$. There were gaps in all questions, especially in question 2 ('Did the pharmacist or pharmacy technician encourage you to ask questions during the consultation?').

This problem has already been recognised by the leadership of the Faculty of Pharmacy at Semmelweis University, which will lead to the introduction of extensive teaching in communication in the undergraduate training of pharmacists from the 2020/2021 academic year. However, the communication training of professionals currently working in community pharmacies is unresolved.

There are several methods for teaching oral communication techniques between professionals and patients in the literature, ${ }^{16-54}$ but due to the limited time and the lack of available teaching staff, a new methodology had to be introduced to effectively train a large number 
Table 4 Staff questionnaire results per question and total (n(preintervention): preintervention questionnaire data number; $\mathrm{n}$ (postintervention): postintervention questionnaire data number; data numbers ( $\mathrm{n}$ ) other than 'the number of professionals surveyed' in the project are due to occasional deficiencies in data collection; $p$ values were determined using variance analysis and t-tests)

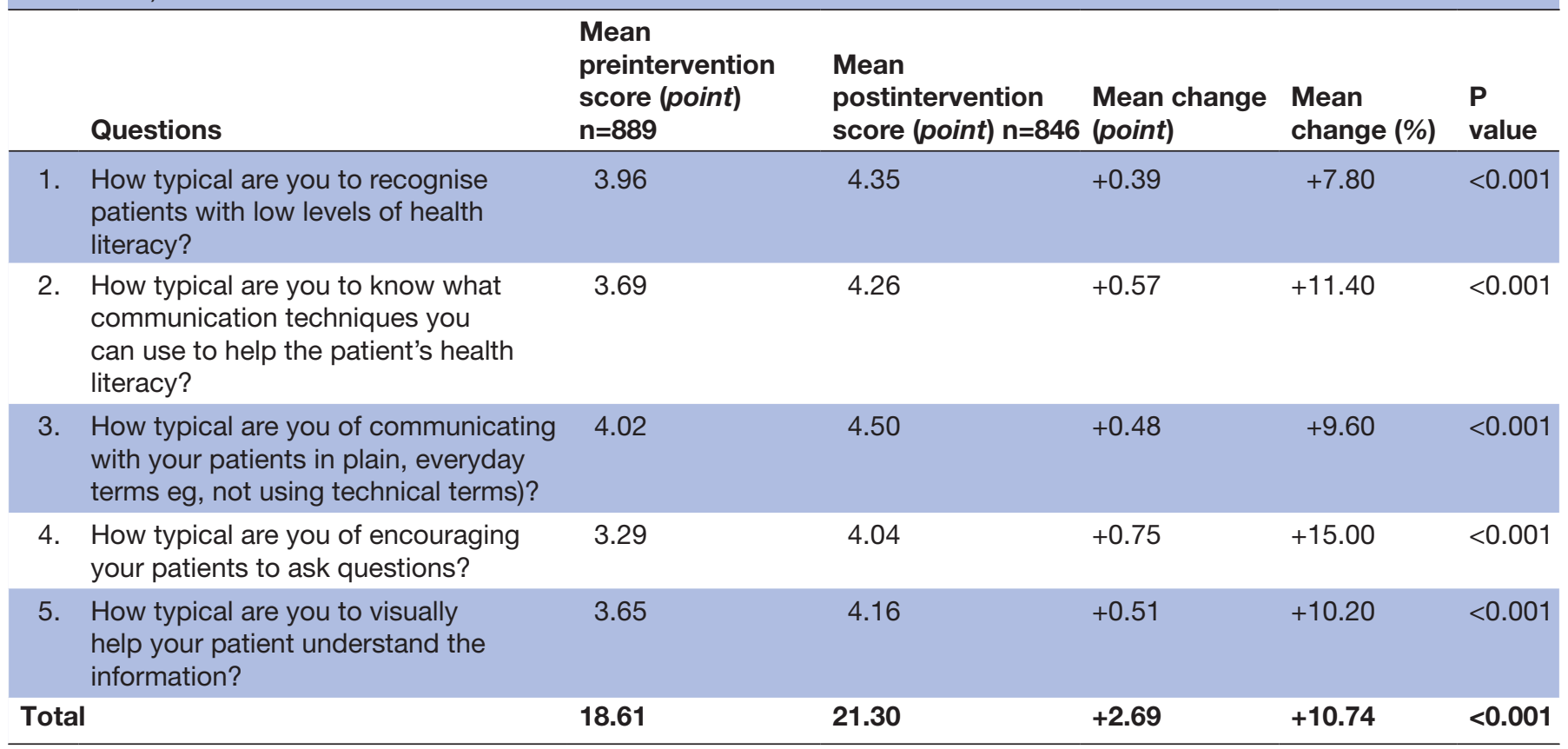

of professionals in a short time. With the postgraduate training methodology discussed in the article, the communication skills of 333 pharmacists and pharmacy technicians were developed in 6 months, with only 76 pharmacists participating in direct training, thanks to the presented 'Train the trainer' methodology, which is

Table 5 Results of staff questionnaires by settlement type (bold: subpopulation with significantly higher improvement; $n$ (preintervention): preintervention questionnaire data number; $n$ (postintervention): postintervention questionnaire data number; data numbers ( $n$ ) other than 'the number of professionals surveyed' in the project are due to occasional deficiencies in data collection; $p$ values were determined using $\chi^{2}$ test and the Kruskal-Wallis test)

\begin{tabular}{|c|c|c|}
\hline Type of settlement & $\begin{array}{l}\text { Mean } \\
\text { change } \\
\text { (point) }\end{array}$ & $\begin{array}{l}\text { Mean } \\
\text { change } \\
(\%)\end{array}$ \\
\hline $\begin{array}{l}\text { Villages } \\
\mathrm{n}(\text { preintervention })=13 \\
\mathrm{n}(\text { postintervention })=14\end{array}$ & +2.29 & +9.16 \\
\hline $\begin{array}{l}\text { Other cities } \\
n(\text { preintervention })=145 \\
n(\text { postintervention })=148\end{array}$ & +2.71 & +10.84 \\
\hline $\begin{array}{l}\text { County towns } \\
n(\text { preintervention })=30 \\
n(\text { postintervention })=30\end{array}$ & +3.23 & +12.92 \\
\hline $\begin{array}{l}\text { Capital } \\
n(\text { preintervention })=143 \\
n(\text { postintervention })=135\end{array}$ & +3.43 & +13.72 \\
\hline$P<0.02$ & & \\
\hline
\end{tabular}

an ideal solution for the communication training of a large number of professional with few available trained instructors.

The success of this method is supported by the opinion of more than 1700 patients surveyed. Examining the patient questionnaire, the results of the questions directly related to communication skills (questions 1-4) show that the methodology introduced can make real progress in the professional application of communication techniques in a short time. By the end of the project, the staff has made the most progress in encouraging the patients to ask questions, in avoiding technical terms, and in adequately emphasising information. The patients in the preintervention and postintervention groups differed, so the development is clearly due to the methodology implemented. For questions 5 and 6 , the indirect effect of the communication techniques (on drug knowledge and sense of health) has been examined. Here, in addition to improving communication, the score is also affected by changes in the patients' condition. As the patients completing the preintervention and postintervention questionnaires differed, we could not detect the change of the latter factor with this methodology, which is why these changes were smaller. To make greater improvement on these issues, longer term and broader adoption is needed. The results show that pharmacy workers have to pay particular attention to the quality of communication with patients over 40 (this includes most of the widows) and/or with lower qualification.

These results are consistent with the results of the staff questionnaire. As mentioned earlier, pharmacists and 
pharmacy technicians did not consider their communication skills to be poor. However, after the project, the professionals saw their abilities even better. Looking at the preintervention and postintervention responses to each question it can be stated that initially, the pharmacy staff rarely encouraged the patients to ask questions (question 4), but by the end of the project, the staff had been able to improve in this, the knowledge and application of communication techniques. This is one of the most essential steps for the patient to actively participate in his/her therapy, which is the basis for collaboration and proper patient adherence. In contrast, training has barely improved the recognition of patients with poor health literacy. The higher development of colleagues working in the capital or county towns may be due to that professionals were trying to spend more time with patients than they did before the project, as pharmacies at these types of settlements generally meet many patients daily, which can make it challenging to provide all the important information due to the lack of time.

The results of the methodology introduced and examined by this study are unique in Hungary. The design and implementation of the project was not an easy task, as it had to adapt to the overload of pharmacists and pharmacy technicians. The aim was to make the methodology compatible with everyday work, due to which there are methodological limitations and shortcomings of the presented study (no randomisation was used, selfdeveloped questionnaires, lack of differentiation between pharmacists and pharmacy technicians), which will be eliminated in the future based on experience. The results and conclusions drawn in the present study provide a comprehensive picture of the necessary introduction of the development of pharmacist communication training in Hungary and the importance and usefulness of the wide-ranging introduction of the pharmacy communication methodology.

\section{CONCLUSIONS}

It can be stated that the presented methodology can be used to develop the communication skills of a large number of professionals in a short time, using a small number of instructors, so it is worthwhile to introduce this methodology as part of compulsory postgraduate training. However, it is even more important to introduce the teaching of communication skills in undergraduate pharmacy training to meet the challenges posed by international trends.

Acknowledgements The authors would like to thank all the pharmacists, pharmacy technicians and pharmacies who contributed to the research. Special thanks to MSD Pharma Hungary for the data collection and to the staff of the Institute of Behavioural Sciences (Semmelweis University) for their help in completing the questionnaires and the 'Train the trainer' presentation.

Contributors AS: formal analysis, investigation, writing —original draft, visualisation. OS: conceptualisation, methodology, validation, writing-review and editing, project administration. AM: formal analysis. KS-P: investigation, project administration. RZ: writing—review and editing, supervision. BH: conceptualisation, supervision.

Funding This work was supported by the ÚNKP-19-3-I New National Excellence Program of the Ministry for Innovation and Technology.

Competing interests None declared.

Patient consent for publication Not required.

Provenance and peer review Not commissioned; externally peer reviewed.

Data availability statement Data are available upon reasonable request.

Supplemental material This content has been supplied by the author(s). It has not been vetted by BMJ Publishing Group Limited (BMJ) and may not have been peer-reviewed. Any opinions or recommendations discussed are solely those of the author(s) and are not endorsed by BMJ. BMJ disclaims all liability and responsibility arising from any reliance placed on the content. Where the content includes any translated material, BMJ does not warrant the accuracy and reliability of the translations (including but not limited to local regulations, clinical guidelines, terminology, drug names and drug dosages), and is not responsible for any error and/or omissions arising from translation and adaptation or otherwise.

Open access This is an open access article distributed in accordance with the Creative Commons Attribution Non Commercial (CC BY-NC 4.0) license, which permits others to distribute, remix, adapt, build upon this work non-commercially, and license their derivative works on different terms, provided the original work is properly cited, appropriate credit is given, any changes made indicated, and the use is non-commercial. See: http://creativecommons.org/licenses/by-nc/4.0/.

ORCID iD

András Szilvay http://orcid.org/0000-0003-4624-5911

\section{REFERENCES}

1 Babinec PM, Rock MJ, Lorenzetti DL, et al. Do researchers use pharmacists' communication as an outcome measure? A scoping review of pharmacist involvement in diabetes care. Int J Pharm Pract 2010;18:183-93.

2 Mossialos E, Courtin E, Naci H, et al. From 'retailers' to health care providers: Transforming the role of community pharmacists in chronic disease management. Health Policy 2015;119:628-39.

3 Moullin JC, Sabater-Hernández D, Fernandez-Llimos F, et al. Defining professional pharmacy services in community pharmacy. Res Social Adm Pharm 2013;9:989-95.

4 Murad MS, Chatterley T, Guirguis LM. A meta-narrative review of recorded patient-pharmacist interactions: exploring biomedical or patient-centered communication? Res Social Adm Pharm 2014;10:1-20.

5 Cadman B, Wright D, Bale A, et al. Pharmacist provided medicines reconciliation within 24 hours of admission and on discharge: a randomised controlled pilot study. BMJ Open 2017;7:e013647.

6 llardo ML, Speciale A. The community pharmacist: perceived barriers and patient-centered care communication. Int J Environ Res Public Health 2020;17. doi:10.3390/ijerph17020536. [Epub ahead of print: 15 Jan 2020].

7 Perrault EK, Beal JL. The effect of pharmacy setting and pharmacist communication style on patient perceptions and selection of pharmacists. J Am Pharm Assoc 2018;58:404-11.

8 Naik Panvelkar P, Armour C, Saini B. Community pharmacybased asthma services--what do patients prefer? J Asthma 2010;47:1085-93.

9 Agomo CO. The role of community pharmacists in public health: a scoping review of the literature. J Pharm Health Serv Res 2012;3:25-33.

10 Weiss MC, Booth A, Jones B, et al. Use of simulated patients to assess the clinical and communication skills of community pharmacists. Pharm World Sci 2010;32:353-61.

11 Kimberlin CL, Jamison AN, Linden S, et al. Patient counseling practices in U.S. pharmacies: effects of having pharmacists hand the medication to the patient and state regulations on pharmacist counseling. J Am Pharm Assoc 2011;51:527-34.

12 Conn VS, Ruppar TM. Medication adherence outcomes of 771 intervention trials: systematic review and meta-analysis. Prev Med 2017;99:269-76.

13 Aina B, Ogunbiyi O. Assessment of communication skills among pharmacy students of the University of Lagos, Lagos, Nigeria. $J$ Basic Clin Pharm 2011;3:215-8.

14 Naughton C. Patient-Centered communication. Pharmacy 2018;6:18. 
15 Berger BA. Patient-Centered care: it's about time. Am J Pharm Educ 2009;73:91.

16 Wallman A, Vaudan C, Sporrong SK. Communications training in pharmacy education, 1995-2010. Am J Pharm Educ 2013;77:36.

17 Kerr A, Strawbridge J, Kelleher C, et al. How can pharmacists develop patient-pharmacist communication skills? A realist review protocol. Syst Rev 2017;6:14.

18 Blom L, Krass I. Introduction: the role of pharmacy in patient education and counseling. Patient Educ Couns 2011;83:285-7.

19 Sørensen K, Van den Broucke S, Fullam J, et al. Health literacy and public health: a systematic review and integration of definitions and models. BMC Public Health 2012;12:80.

20 Veenker $\mathrm{H}$, Paans W. A dynamic approach to communication in health literacy education. BMC Med Educ 2016;16:280.

21 Sørensen K, Pelikan JM, Röthlin F, et al. Health literacy in Europe: comparative results of the European health literacy survey (HLS-EU). Eur J Public Health 2015;25:1053-8.

22 Koltai J, Kun E. [The practical measurement of health literacy in Hungary and in international comparison]. Orv Hetil 2016;157:2002-6.

23 Leestma JE. Pharmacy practice, 2017.

24 WHO. The role of the pharmacist in the health care system: preparing the future pharmacist: curricular development: report of a third who consultative group on the role of the pharmacist, Vancouver, Canada, 27-29 August 1997. Geneva: World Health Organization, 1997.

25 Puspitasari HP, Aslani P, Krass I. A review of counseling practices on prescription medicines in community pharmacies. Res Social Adm Pharm 2009;5:197-210.

26 McGuire LC. Remembering what the doctor said: organization and adults' memory for medical information. Exp Aging Res 1996;22:403-28.

27 Dickson D, Hargie O, Morrow N. Communication skills training for health professionals. Chapman and Hall Medical, 1996.

28 Zolnierek KBH, Dimatteo MR. Physician communication and patient adherence to treatment: a meta-analysis. Med Care 2009;47:826-34.

29 Rao JK, Weinberger M, Kroenke K. Visit-specific expectations and patient-centered outcomes: a literature review. Arch Fam Med 2000;9:1148-55.

30 PSI. Core competency framework for pharmacists, 2013. Available: https://www.thepsi.ie/Libraries/Pharmacy_Practice/PSI_Core_Comp Framework_Web_Version_Final.sflb.ashx; [Accessed 28 Feb 2020].

31 Powell CK, Hill EG, Clancy DE. The relationship between health literacy and diabetes knowledge and readiness to take health actions. Diabetes Educ 2007;33:144-51.

32 PCNZ. Competence standards for the pharmacy profession, 2015. Available: https://enhance2.psnz.org.nz/assets/downloads/group_ three/reflection/Standards_2015_FINAL.pdf; [Accessed 28 Feb 2020].

33 NAPRA. Professional competencies for Canadian pharmacists at entry to practice. Available: https://napra.ca/sites/default/files/201708/Comp_for_Cdn_PHARMACISTS_at_EntrytoPractice_March2014_ b.pdf; [Accessed 28 Feb 2020].

34 FIP. A global competency framework, 2012. Available: https://www. fip.org/files/fip/PharmacyEducation/GbCF_v1.pdf; [Accessed 28 Feb 2020].

35 Greenhill N, Anderson C, Avery A, et al. Analysis of pharmacistpatient communication using the Calgary-Cambridge guide. Patient Educ Couns 2011;83:423-31.

36 van Hulten R, Blom L, Mattheusens J, et al. Communication with patients who are dispensed a first prescription of chronic medication in the community pharmacy. Patient Educ Couns 2011;83:417-22.
37 Kimberlin CL. Communicating with patients: skills assessment in US colleges of pharmacy. Am J Pharm Educ 2006;70:67.

38 Mesquita AR, Lyra DP, Brito GC, et al. Developing communication skills in pharmacy: a systematic review of the use of simulated patient methods. Patient Educ Couns 2010;78:143-8.

39 Walpola RL, Fois RA, McLachlan AJ, et al. Evaluating the effectiveness of a peer-led education intervention to improve the patient safety attitudes of junior pharmacy students: a crosssectional study using a latent growth curve modelling approach. BMJ Open 2015;5:e010045

40 Cleland J, Bailey K, McLachlan S, et al. Supplementary pharmacist prescribers' views about communication skills teaching and learning, and applying these new skills in practice. Int J Pharm Pract 2007;15:101-4.

41 Pilling J. Az egészségmüveltség jelentősége a gyógyszerészi gyakorlatban. Available: http://semmelweis.hu/gytk/files/2017/02/ Eg\%C3\%A9szs\%C3\%A9gm\%C5\%B1velts\%C3\%A9g-train-thetrainer-el\%C5\%91ad\%C3\%A1s.pptx; [Accessed 14 July 2019].

42 National Adult Literacy Agency. Cristal clear mark. Available: https:// www.nala.ie/health-literacy/crystal-clear-mark/; National Adult Literacy Agency [Accessed 16 Jan 2020].

43 Act XLVII of 1997 on the management and protection of health data and related personal data, 1997. Available: https://net.jogtar.hu/ jogszabaly?docid=99700047.tv [Accessed 02.02.2020].

44 Regulation No 41/2007. Regulation no 41/2007 Ministry for health on the operation, service and registration ofpublic, branch, manual and Institute pharmacies. Magyar Közlöny 2007.

45 Ministry of Health. Regulation no 44/2004 MoHSFA on the ordering and issuing of medicinal products for human use, S.a.F.A.. Magyar Közlöny 2004:00001-415

46 Capacities, M.o.H. A profession Directive on medication review in the framework of basic pharmaceutical care, 2013. Available: http:// hbcs.hu/uploads/jogszabaly/1529/fajlok/gyogyszerbiztonsagi_ ellenorzes.pdf [Accessed 22 Nov 2018].

47 Act No. CLIV of 1997 on health, 1997. Available: https://net.jogtar.hu/ jogszabaly?docid=99700154.tv [Accessed 02.05.2020.].

48 Hess R, Hagemeier NE, Blackwelder R, et al. Teaching communication skills to medical and pharmacy students through a blended learning course. Am J Pharm Educ 2016;80:64.

49 Jin HK, Park SH, Kang JE, et al. The influence of a patient counseling training session on pharmacy students' self-perceived communication skills, confidence levels, and attitudes about communication skills training. BMC Med Educ 2019;19:172.

50 Hanya M, Kanno Y, Akasaki J, et al. Effects of communication skill training (CST) based on spikes for insurance-covered pharmacy pharmacists to interact with simulated cancer patients. J Pharm Health Care Sci 2017;3:11.

51 Gillette C, Rudolph M, Rockich-Winston N, et al. Improving pharmacy student communication outcomes using standardized patients. Am J Pharm Educ 2017;81:110.

52 Kubota R, Shibuya K, Tanaka Y, et al. Clinical pharmacy education in Japan: using simulated patients in laboratory-based Communication-Skills training before clinical practice. Pharmacy 2018;6:49.

53 Begley K, Haddad AR, Christensen C, et al. A health education program for underserved community youth led by health professions students. Am J Pharm Educ 2009;73:98.

54 Sookaneknun P, Suttajit S, Ploylearmsang C, et al. Health promotion integrated into a Thai PharmD curriculum to improve pharmacy practice skills. Am J Pharm Educ 2009;73:78. 